\title{
Progress in South American Dendrochronology
}

Jose A. Boninsegna

Laboratorio de Dendrocronologia, IANIGLA-CONICET, Mendoza, Argentina; pbonin@lab.cricyt.edu.ar

\section{Climate and Ecosystems}

South America extends from $11^{\circ} \mathrm{N}$ to $62^{\circ} \mathrm{S}$. Major boundaries such as the Andes on the western side of the continent and the land mass in the tropics create north-south and west-east variations in climate and ecosystems. Tropical forest covers $44 \%$ of the total land surface. Between 36 and $56^{\circ} \mathrm{S}$, a temperate forest composed of high longevity trees dominates. The northern and central highlands are covered by small trees, shrubs and grasses. The central western part (Peru, Chile, the Andes, western Argentina and eastern Patagonia) is composed of deserts. These diverse climatic zones and ecosystems offer various potential sites for dendrochronological studies. The ideal conditions for paleoclimatic reconstructions using tree-rings are those that support the existence of long-living trees required to develop long chronologies, and/or the presence of subfossil woods. Over the last decade, the search for areas with some of these conditions has been one of the major goals of dendroclimatological studies in South America.

Dendrochronological studies in South America started in the temperate region, where conifer and broad-leaf species with well marked annual rings grow (Boninsegna and Villalba 1996). Following this initial period, interest in tree-ring studies spread throughout the region and several scientific centers in Argentina, Brazil, Bolivia, Chile and Peru are now using dendrochronological techniques to assess questions related to paleoclimate, forest ecology, biogeography, and forest production.

\section{Long Chronologies}

South American high longevity tress offer the possibility of reconstruction on long temporal scales. Long tree-ring chronologies have been developed in recent years using Fitzroya cupressoides (Alerce).

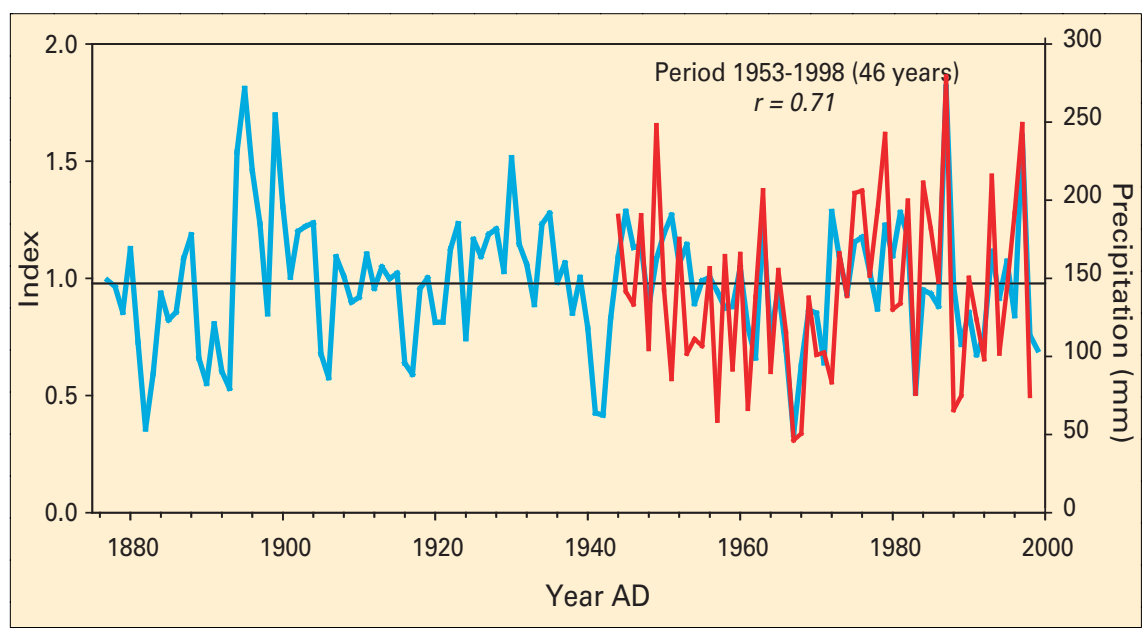

Fig. 1: Polylepis tarapacana chronology developed by Argollo and Villalba in 2001 (personal communication) at Volcan Tunupa $\left(19^{\circ} \mathrm{S}, 4600 \mathrm{~m}\right.$. a.s.l.). The chronology is drawn in blue, while the dark red line correspond to precipitation data from Oruro (Bolivia).

Fitzroya is a conifer growing between $40^{\circ}$ and $43^{\circ} \mathrm{S}$ and reaching ages of about 3,000 years. A network of 20 chronologies over 1,000 years long is already available in Argentina and Chile and a 5,100-year chronology is being developed in Chile (Wolodarsky, personal communication).

Austrocedrus chilensis is another long-lived conifer growing in north-western Patagonia (32 to 39 $\left.{ }^{\circ} \mathrm{S}\right)$. It is possible to find living trees $900-1,000$ years old. A network of 27 chronologies from Austrocedrus chilensis has been used to reconstruct past precipitation variations in northern Patagonia since A.D. 1600. Recently, a new set of millennial scale chronologies (using living trees and sub-fossils) have been produced. A combination of ring width, $\delta^{18} \mathrm{O}$ and density chronologies is being used to study El Niño Southern Oscillation (ENSO) variability in this sensitive region.

\section{Sub-fossil Wood}

Often, the acidity in peat bogs provides conditions that permit the preservation of stumps. On Tierra del Fuego Island $\left(51^{\circ}-56^{\circ} \mathrm{S}\right)$, peat bogs are rather common. Samples extracted from different places yield radiocarbon dates ranging between 3,000 to 4,000 years. A floating chronology is now available and ex- tensive sampling is being carried out in order to fill the gap between the floating and the "living trees" chronologies (Roig 2002 personal communication).

Tree rings are routinely used to reconstruct Holocene climate variations at high temporal resolution, but only rarely have they offered insight into climate variability during earlier periods. Roig et al. (2001) reported a floating 1,229-year chronology developed from sub-fossil stumps of Fitzroya cupressoides in southern Chile $\left(41.4^{\circ} \mathrm{S}\right)$ dating to ca. $50,000{ }^{14} \mathrm{C}$ years B.P. They used this chronology to calculate the spectral characteristics of climate variability at that time, which was probably an interstadial (relatively warm) period. A comparison with the power spectra of chronologies derived from living $F$ cupressoides trees shows strong similarities with the 50,000-year-old chronology, indicating that similar growth forcing factors operated in this glacial interstadial phase, as during the current interglacial conditions.

\section{Chronology Network}

The existing chronology coverage of South America is patchy and largely concentrated in the temperate region of Argentina and Chile. In the last three years, an important number of new chronologies 


\section{Science Highlights}

(ca. 85) using the southern beech Nothofagus pumilio have been produced in the southern part of Argentina and Chile (Lara et al. 2001). An important product based on this network is a 400 years reconstruction of meridional and zonal atmospheric circulation index over the Southern Ocean (50-60S). The zonal index shows dominant modes of variation at 4.4 - 5 year period, which may be associated with the Antarctic Circumpolar Wave. The meridional index shows that the $19^{\text {th }}$ century was dominated by southerly flow; while during the $20^{\text {th }}$ century northerly flow prevailed over the region. These results are consistent with the warming observed in the Southern Ocean in recent decades (Villalba et al. 2002 in prep.).

An interesting number of chronologies developed from Cedrela lilloi and Juglans australis from the cloudy montane forest known as the "Yungas" $\left(22-25^{\circ} \mathrm{S}\right)$ in the subtropical region of Argentina were successfully used in estimating past changes in precipitation (Villalba et al 1998). Additional chronologies in the same area are under development in an effort to extend the temporal scale.

\section{Tropical Chronologies}

Reconstruction of low latitude climate variability has been hampered by the lack of suitable annually resolved proxy climate records. Several factors can be invoked to explain the unbalanced distribution of tree-ring records between tropical and temperate regions in the Americas. Most tropical species do not form distinct rings and when rings are present, they are not annual. Some species show clearly visible rings but the circular uniformity is uncertain. Absence of seasonality appears to be the main reason for the lack of well-defined boundary rings in the tropics. Nevertheless, there are tropical and subtropical regions that experience seasonal changes in precipitation or temperature that can induce the formation of defined growth rings. In order to fill the "tropical gap" between the presently available

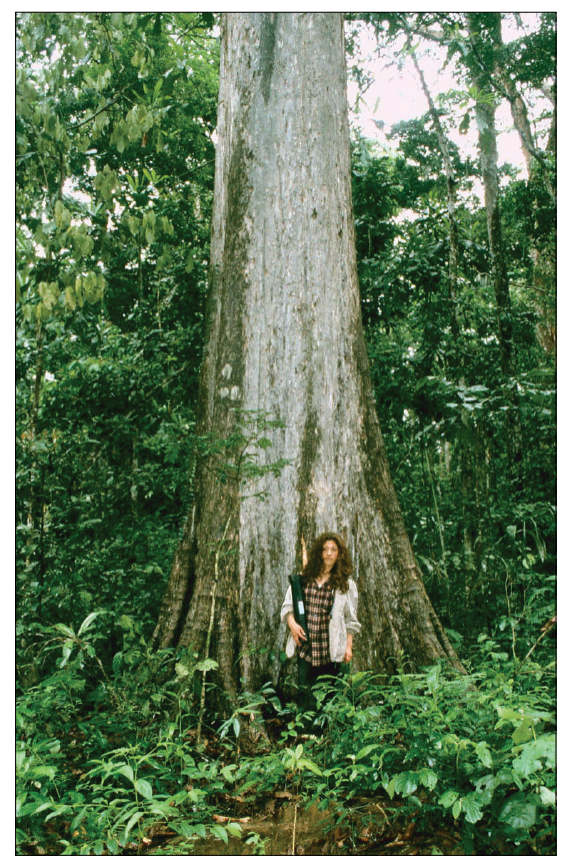

Fig. 2: Cedrela odorata tree growing at Pando, Bolivia $\left(11^{\circ} \mathrm{S} 200 \mathrm{~m}\right.$ a.s.l.) in the southwestern part of the Amazon basin. The climate presents a mean annual temperature of $27^{\circ} \mathrm{C}$ and $1800 \mathrm{~mm}$ of precipitation with a marked dry period during the months of May to September. The diameters of the dominant trees reach 1.0 - 1.5 meters (Photo: F. Roig).

tree-ring chronology networks, scientist from Argentina and Bolivia are working together in the search of woody species suitable for dendrochronological research.

\section{High Altitude Chronologies}

Highlands are climate-sensitive sites of particular interest to tree-ring research in tropical and subtropical regions. In the South American subtropics $\left(15^{\circ}-25^{\circ} \mathrm{S}\right)$, the moderate seasonality of temperature may induce the formation of well-defined rings more effectively at colder treeline environments. At lower elevations in the Bolivian subtropics, the presence of annual growth bands may be related to the occurrence of dry-wet cycles and/or flood conditions. Because it is adapted to dry and cold conditions, Polylepis tarapacana reaches the highest elevation (between 4100 and $5200 \mathrm{~m}$ ) of tree growth in the world. Some living $P$. tarapacana trees are known to reach ca. 600 years of age indicating the potential for long chronologies. One of these chronologies, at Tunupa $\left(19^{\circ} 45^{\prime} \mathrm{S}\right)$, shows a remarkable correlation with precipitation as illustrated in
Fig. 1. Presently, four chronologies are available at Volcan Sajama, Volcan Tunupa, Soniquera and Volcan Granadas. The Soniquera chronology covers the interval AD 1411-2000. Bolivian chronologies are the highest elevation tree-ring chronologies in the world.

In Piura (Peru) Rodríguez and Córdova (2001, pers. comm.) successfully developed a tree-ring chronology using Bursera graveolens at Vicus Hill $\left(5^{\circ} 9^{\prime} \mathrm{S}\right)$. The 38 -year old series recorded the last two mega ENSO events (1982-83 and 1997-98). This important result suggests that dendroclimatological reconstruction of El Niño-Southern Oscillation (ENSO) in Peruvian north coast is possible.

\section{Amazonian Chronologies}

The complex Amazonian forest is a true challenge for dendrochronology. Several attempts to explore the potential for new species to yield annual ring series have been carried out in different regions. Most of these studies were conducted in species of the Meliaceae family, in particular Sweitenia mycrophilla and Cedrela odorata. In a recent work, C. odorata sampled at Pando, in Bolivia $\left(11^{\circ} \mathrm{S}\right)$ showed visible and circularly uniform rings, and reached ages of ca. 250 years (Roig pers. comm., Fig. 2). Strong variations in the width of the rings suggest high sensitivity to the variations of a common factor in the stand, probably climate or a climate-related phenomenon. C. odorata has a wide latitudinal range, from the northern part of Mexico through the Amazonia basin as far as approximately $24^{\circ} \mathrm{S}$, making the species a good candidate to develop a chronology network.

Thanks partly to the efforts of the PAGES Focus I Pole-EquatorPole Transect (PEP-I), and with the support of the Interamerican Institute for Global Change Research (IAI), a collaborative project involving 15 investigators from 15 institutions in Argentina, Bolivia, Canada, Chile, Mexico, Peru and the USA aims to develop a comprehensive geographical coverage of tree-ring treeline chronologies. It is expect- 


\section{Science Highlights}

ed that they will allow the reconstruction of global-scale spatial and temporal patterns of temperature and precipitation along this transect over the last several hundred years and to encourage the training of scientist and the application of dendrochronology and paleoenvironmental science within Latin America (Luckman and Boninsegna, 2002).

\section{ACKNOWLEDGMENTS}

I thank J. Argollo and R. Villaba for providing

the data used in figure 1.

\section{REFERENCES}

Boninsegna, J. A. and Villalba, R., 1996, Dendroclimatology in the Southern Hemisphere: Review and Prospects. In: Tree Rings, Environments and Humanity. Ed. J.S. Dean; D.M.Meko and T. WSwetnam. Radiocarbon 1996, pp 127-141

Lara, A; Aravena J.C., Villalba, R., Wolodarsky-Franke, A., Luckman, B. and Wilson, R., 2001, Dendroclimatology of high-elevation Nothofagus pumilio forest at their northern distribution limit in the Central Andes of Chile. Can. J. of For. Res., 31, 925-936.
Luckman, B. and Boninsegna, J.A. 2001, The Assessment of Present, Past and Future of Climatic Variability in the Americas from Tree-Line Environments, PAGES News $\mathbf{9}(\mathbf{3}), 17-19$

Roig, F. A, Le-Quesne, C.; Boninsegna, J. A; Briffa, K. R., Lara, A., Gruddk, H., Jones, P.D. and Villagran, C., 2001, Climate variability 50,000 years ago in mid-latitude Chile as reconstructed from tree rings, Nature ,410, 567-570

Villalba, R, Grau, H.R., Boninsegna, J.A., Jacoby, G. and Ripalta, A., 1998, Tree-ring evidence for long term precipitation changes in subtropical South America, International Journal of Climatology, 18, 1463-1478

\section{Post-fire Vegetation Dynamics in Southern Switzerland}

\section{Marco Conedera ${ }^{1}$ and Willy Tinner ${ }^{2}$}

1 WSL Sottostazione Sud delle Alpi, CH-6504 Bellinzona; marco.condera@wsl.ch

2 Institut für Pflanzenwissenschaften der Universität Bern, Altenbergrain 21, CH-3013 Bern; willy.tinner@ips.ch

\section{Introduction}

Because forest fires in central Europe are rare compared to North America, knowledge about the postfire behavior of native European species is scanty. The expected climate change for the next century could influence fire regimes in central Europe thereby leading to more frequent forest fires. Thus, knowledge about post-fire behaviour and fire-sensitivities of central-European plant species may become more important for understanding and managing forest ecosystems.

In Switzerland most fires occur in the region south of the Alps during the early spring season (March to April). During this period the deciduous forest belt is threatened by fast spreading surface fires that, in certain cases, represent a very important disturbance factor (Conedera et al. 1996). It is well known that the vegetation shows different reaction patterns to fire depending on the life strategy of the species and the fire regime (Bond and van Wilgen 1996, Hofmann et al. 1998), but because fire affects species composition at timescales of years to centuries, direct observation of the full range of post-fire vegetational change is not possible. To overcome this difficulty, we combine paleoecological, dendroecological and phytosociological methods in order to (1) determine vegetation response patterns

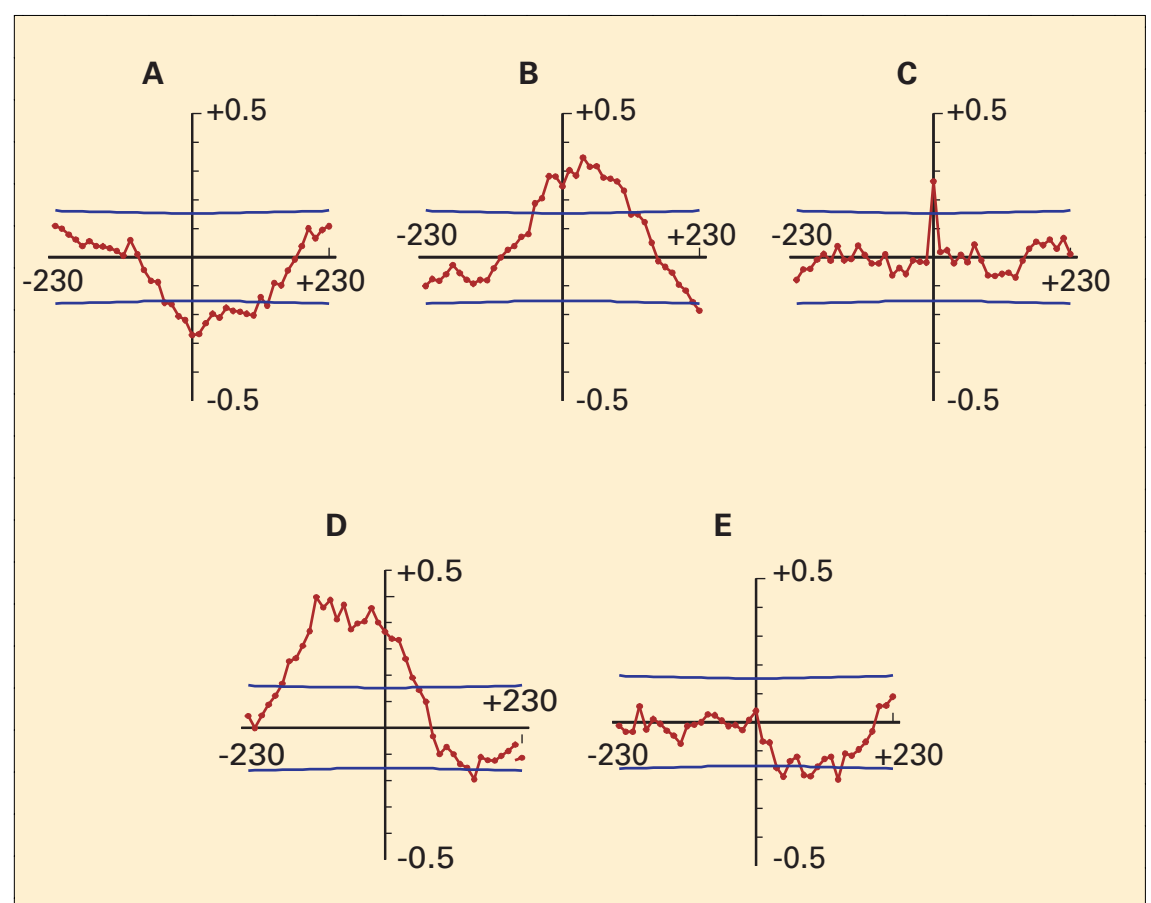

Fig. 1: Correlograms of charcoal influx, pollen percentages and diversity from Lago di Origlio $(5,100-3,100 \mathrm{BC}$ cal.). Horizontal axis shows lag in years (one lag $=11.6$ years). Vertical axis shows correlation coefficient - those outside the lines are significant at $p=0.05$. A: decreasing taxa (charcoal vs. Ulmus spp.); B: increasing taxa (charcoal vs. Alnus glutinosa t.); C: opportunists (charcoal vs. Cichorioideae); D: fire precursors (charcoal vs. Pteridium aquilinum); $\boldsymbol{E}$ : plant diversity (charcoal vs. pollen diversity).

during different historical periods and fire regimes and (2) provide information on related long-term ecosystem dynamics.

\section{Paleoecology}

Sediment analyses of two small lakes (Lago di Origlio and Lago di Muzzano) were used to reconstruct vegetation history and fire ecology of the last 15,000 years (Tinner et al. 1999). A comparison of the recent sedimentary record with the wildfire database of southern Switzerland indicates that charcoal concentration and influx estimated from pollen slides correlate well with the number of forest fires occurring within a distance of 20 to 50 $\mathrm{km}$ from the coring site (Tinner et al. 1998). In order to determine postfire vegetation responses, we computed cross-correlations for pairs of pollen types and charcoal concen- 